\title{
Quantifying the Loss of a Marine Ecosystem Service: Filtration by the Eastern Oyster in US Estuaries
}

\author{
Philine S. E. zu Ermgassen • Mark D. Spalding • \\ Raymond E. Grizzle • Robert D. Brumbaugh
}

Received: 7 June 2012 /Revised: 11 September 2012 / Accepted: 17 September 2012 / Published online: 2 October 2012

(C) The Author(s) 2012. This article is published with open access at Springerlink.com

\begin{abstract}
The oyster habitat in the USA is a valuable resource that has suffered significant declines over the past century. While this loss of habitat is well documented, the loss of associated ecosystem services remains poorly quantified. Meanwhile, ecosystem service recovery has become a major impetus for restoration. Here we propose a model for estimating the volume of water filtered by oyster populations under field conditions and make estimates of the contribution of past (c. 1880-1910) and present (c. 20002010) oyster populations to improving water quality in 13 US estuaries. We find that filtration capacity of oysters has declined almost universally (12 of the 13 estuaries examined) by a median of $85 \%$. Whereas historically, oyster populations achieved full estuary filtration (filtering a volume equivalent or larger than the entire estuary volume within the residence time of the water) in six of the eight estuaries in the Gulf of Mexico during summer months, this is now the case for only one estuary: Apalachicola Bay, Florida. By contrast, while all five estuaries on the North Atlantic coast showed large decreases in filtration capacity, none were achieving full estuary filtration at the time of our c. 1900 historic baseline. This apparent difference from the
\end{abstract}

P. S. E. zu Ermgassen $(\bowtie)$

Department of Zoology, University of Cambridge,

Cambridge CB2 3EJ, UK

e-mail: philine.zuermgassen@cantab.net

\section{D. Spalding}

Global Marine Team, The Nature Conservancy,

Department of Zoology, University of Cambridge,

Cambridge CB2 3EJ, UK

\section{R. E. Grizzle}

Department of Biological Sciences, University of New Hampshire, Durham, NH 03824, USA

R. D. Brumbaugh

Global Marine Team, The Nature Conservancy,

Big Pine Key, FL 33043, USA
Gulf of Mexico is explained at least in part by our North Atlantic baseline representing a shifted baseline, as surveyed populations were already much reduced by exploitation in this region.

Keywords Crassostrea virginica $\cdot$ USA · Restoration · Estuarine habitat $\cdot$ Historical ecology $\cdot$ Water quality

\section{Introduction}

The accelerated loss of many habitats since the industrial revolution is widely documented (Winslow 1887; Roberts 2002; Fearnside 2005); however, the ecological and social ramifications of this loss have only recently gained recognition (Millennium Ecosystem Assessment 2005). Quantifying losses and the impact of habitat alteration is challenging, as long-term data on habitat area or condition are rare. The vast majority of habitats represented in historic datasets lack detailed insights beyond areal extent (e.g., Sommer 1976; Bromberg and Bertness 2005), yet habitat degradation is frequently a threat in addition to habitat loss (Lambin 1999; Turner et al. 1999; zu Ermgassen et al. 2012). In many marine environments, it is difficult, if not impossible, to determine the nature of pristine habitats that have been lost (Roberts 2007). This is problematic in deriving estimates of ecosystem service provision historically, as many services are strongly dependent on species abundance or species richness (Diaz et al. 2006; Gibbs et al. 2007). In these cases, knowledge of the change in habitat quality may be necessary to determine the change in ecosystem service delivery as habitats degrade.

Oyster reefs are among the most threatened of marine habitats having suffered substantial declines globally over the past century (Beck et al. 2011), primarily due to overfishing, hydrological changes, pollution, and disease (Winslow 1887; Mackenzie 2007; Powell et al. 2008; Wilberg et al. 
2011). These losses have been quantified for the USA, where zu Ermgassen et al. (2012) utilized data on oyster size and density alongside spatial extent measures to derive estimates of a $64 \%$ decline in oyster extent and $88 \%$ loss of oyster biomass between the early 1900s and the early 2000s. Such measures underpin efforts to formulate estimates of the loss of a critical coastal ecosystem service-water filtration.

Filtration by suspension feeders such as oysters impacts water quality by directly removing particulate matter from the water column, with oysters ingesting the edible particles and binding rejected particles with mucus, then depositing this as pseudofeces onto the sediment surface. Through this action, both phytoplankton and suspended sediment that would otherwise reduce water clarity are drawn from the water column to the benthos. The eastern oyster, Crassostrea virginica (Gmelin, 1791), is known to filter particles $>5 \mu \mathrm{m}$ in size with high efficiency (Riisgaard 1988) and can have a marked effect on light penetration in shallow, calm waters, which in turn may have positive impacts on other important adjacent habitats, such as seagrass beds (Newell and Koch 2004).

The physiology of oyster feeding and filtration is well studied, and filtration rate is known from laboratory studies to be influenced by a variety of environmental factors such as temperature, flow rate, salinity, seston concentration, and particle size, as well as oyster size (Loosanoff 1958; Walne 1972; Shumway et al. 1985; Riisgaard 1988). Although it is recognized that conditions in situ may significantly affect filtration rate (Doering and Oviatt 1986; Powell et al. 1992), few studies have sought to quantify rates under field conditions. To estimate the contribution of oyster filtration within an estuary, one can model field-based filtration rates by summing the effect of environmental variables, for which the relationships have been derived and for which field measurements are available. This has been done effectively for Chesapeake Bay (Cerco and Noel 2005; Fulford et al. 2007); however, such methods are expensive and require the input of a large amount of environmental data and computational capacity (Cerco and Noel 2005). While the required environmental data are available for well-studied estuaries such as Chesapeake Bay, they are not available for most other estuaries, and therefore, such high-resolution models are not widely applicable.

In addition to the challenges posed by the lack of data, there remain concerns that oysters in situ may not respond as predicted by models primarily based on filtration by few oysters in the laboratory. Oyster populations in situ may spend a different proportion of time with their valves shut, there is the potential for synergistic population-level influences and re-filtration, and physical attributes of the reef may influence flow dynamics and hence the uptake of particles (Dame et al. 1984; Harsh and Luckenbach 1999). Despite these concerns, it seems that models may be the only means available to estimate filtration rates at large scales.

In order to make broad, estuary-scale estimates of the volume of water filtered by oyster populations nationally, we derived a model of oyster filtration based on the only in situ measurements of oyster filtration currently available (Grizzle et al. 2006, 2008). We use this model to explore the estimated delivery of this ecosystem service historically versus presently across 13 US estuaries.

\section{Methods}

Of the multiple variables known to influence oyster filtration, we determined that water temperature and oyster size (shell height from umbo to the posterior edge; $\mathrm{SH}$ ) were the key variables for which we could obtain data nationally (Table 1). Other variables included dissolved oxygen and salinity which illicit near "all or nothing" responses (Churchill 1920; Cerco and Noel 2005) and hence are likely to be transient features where oysters are found in abundance. Finally, variables such as flow rate and seston quality and concentration vary on small spatial and temporal scales (Berg and Newell 1986; Wilson-Ormond et al. 1997) and can therefore not be modeled on the estuarywide and national scale used in our study, but equally are likely to be of lesser importance in estimating filtration rates at these large scales.

In order to account for field conditions in our model, we used the field measurements of seston uptake over natural oyster reefs reported in Grizzle et al. $(2006,2008)$ to estimate filtration rates. Grizzle et al. measured seston drawdown over reefs with a known mean oyster SH and density, and under optimal temperature conditions. We assumed that all seston drawdown was the result of filtration by oysters and estimated the mean filtration rate per oyster for each reef surveyed. We subsequently fitted a standard filtration model (Eq. 1) to these field data. SH to dry tissue mass conversions from the respective regions (South Carolina and Florida) were applied. Field data were collected on intertidal reefs during both ebb and flood tides (Grizzle et al. 2006, 2008) and therefore captured the impact of the tidal cycle (Dame et al. 1984, 1992). Negative values caused by waves or other disturbances were excluded.

Filtration rates were estimated to increase nonlinearly as a function of oyster biomass following the relationship outlined in Eq. 1 (Newell and Langdon 1996).

$F R=a W^{b}$

where $a$ and $b$ are constants and $W$ is oyster dry tissue mass in grams.

A recent review by Cranford et al. (2011) suggested that the constant $b$ could be universally written as 0.58 for filter- 
Table 1 Overview of variables effecting oyster filtration rate

\begin{tabular}{|c|c|c|c|}
\hline Variable & Effect on filtration rate & Reference & Data description \\
\hline Temperature & Unimodal with optimum filtration at $\sim 27^{\circ} \mathrm{C}$ & Newell and Langdon (1996) & Mean available nationally \\
\hline Salinity & $\begin{array}{l}\text { Steep decline in filtration rate between } \\
14 \text { and } 10 \mathrm{ppt}\end{array}$ & Churchill (1920) & $\begin{array}{l}\text { Varies dramatically spatially } \\
\text { within estuaries }\end{array}$ \\
\hline $\begin{array}{l}\text { Dissolved } \\
\text { oxygen }\end{array}$ & Unknown. Modeled as strong decrease $<2 \mathrm{mg} / 1$ & Cerco and Noel (2005) & $\begin{array}{l}\text { Rare, variable at a small spatial } \\
\text { scale }\end{array}$ \\
\hline Particle size & Retain particles $>5 \mu \mathrm{m}$ at high efficiency & Riisgaard (1988) & Rare, varies seasonally \\
\hline $\begin{array}{l}\text { Seston } \\
\text { concentration }\end{array}$ & $\begin{array}{l}\text { Maximal when seston concentration }>5 \\
\text { and }<10 \mathrm{mg} / 1\end{array}$ & $\begin{array}{l}\text { Epifanio and Ewart (1977), } \\
\text { Newell and Langdon (1996) }\end{array}$ & Rare, varies seasonally \\
\hline Flow rate & Effect poorly understood & $\begin{array}{l}\text { Newell and Langdon (1996), } \\
\text { Harsh and Luckenbach (1999) }\end{array}$ & $\begin{array}{l}\text { Rare, variable at a small spatial } \\
\text { scale }\end{array}$ \\
\hline Oyster size & $\begin{array}{l}\text { Increases as a function of dry mass by an } \\
\text { exponent of } 0.58\end{array}$ & $\begin{array}{l}\text { Newell and Langdon (1996), Cranford et } \\
\text { al. (2011) }\end{array}$ & Mean available nationally \\
\hline
\end{tabular}

feeding bivalves. While species-specific estimates for $C$. virginica are rare, they have ranged from 0.59 (Pruder et al. 1976 cited in Epifanio and Ewart 1977) to $0.73 \pm 0.22$ (Riisgaard 1988). Using the Levenberg-Marquardt nonlinear least squares method (Press et al. 2007) in Mathematica version 7, we fitted Eq. 1 to the field data, once allowing both $a$ and $b$ to be estimated and once setting $b$ at the fixed value of 0.58 . We then performed an $F$ test to determine that we were not justified in estimating $b$ and were justified in using the $b$ value from the literature ( $F$ test; $F_{9,1}=0.07$, $P=0.2$; Fig. 1).

We combined the resulting equation with a function for the effect of temperature proposed by Cerco and Noel (2005) to give Eq. 2.

$F R=8.02 W^{0.58} e^{(-0.015 T-27)^{2}}$

where $T$ is temperature in degrees Celsius.

We selected 13 estuaries for which historic (ca. 18801910) and present (ca. 2000-2010) oyster data were

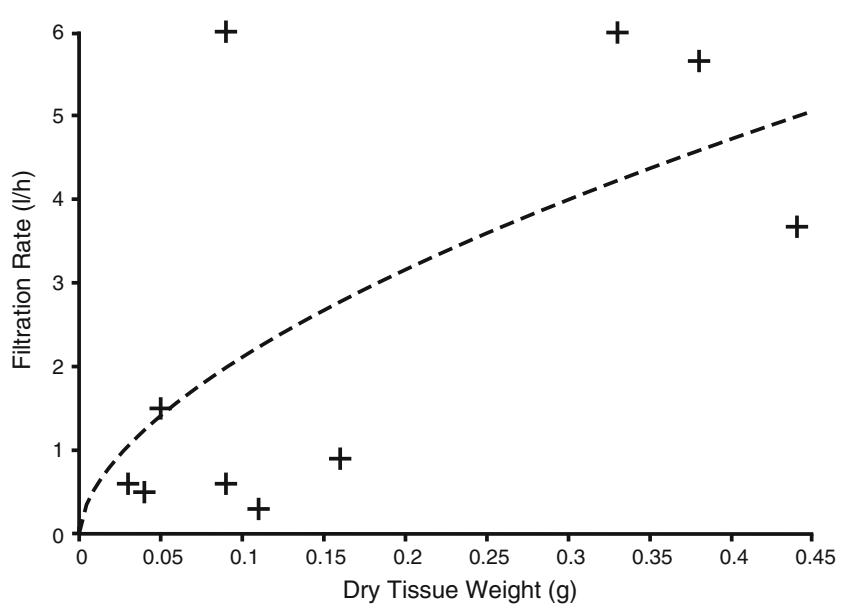

Fig. 1 Fitted model of filtration, as represented in Eq. 2, fitted to the field data collected in situ. Model as in Eq. $2, R_{\mathrm{adj}}{ }^{2}=0.71$ available from zu Ermgassen et al. (2012) (Table 2). The motivations for mapping oyster reef habitat have remained constant over time, the primary goal being to determine the extent and status of oyster grounds available for fishing. The physical nature of oyster reefs, as islands of textured hard substrate in otherwise soft bottom, allowed for the early accurate mapping of this subtidal habitat. In this respect, oyster reefs provide a unique historical dataset. In the vast majority of cases, historical surveying entailed initial surveys of oystermen, followed by detailed transects of the estuary bottom, dragging chains to detect changes in the nature of the substrate and ground truthing through subsequent sampling (see Moore 1910 for a detailed overview of a typical sampling method and zu Ermgassen et al. 2012 for further information regarding data handling and comparisons). This methodology provides accuracy not dissimilar to modern day side-scan sonar that is typically used to determine the present day extent of subtidal oyster reefs. As in zu Ermgassen et al. (2012), we therefore assume equivalence in the spatial extent delimited by these two methods. Both modern and historic sampling provided data on the $\mathrm{SH}$ and density for two oyster size classes; those above $75 \mathrm{~mm} \mathrm{SH}$ and those between 25 and $75 \mathrm{~mm} \mathrm{SH}$. Spat (oysters $<25 \mathrm{~mm} \mathrm{SH}$ ) were excluded, as the quantification of spat is variable between studies. In some cases, historic density and SH data were proxied from neighboring estuaries within the same ecoregion (see zu Ermgassen et al. 2012). SH was converted to dry tissue mass in grams using regionally specific conversions (Liddel 2008; Mann et al. 2009a, b; Harding et al. 2010; Beseres Pollack et al. 2011; Bushek, unpublished data). Where estuary-specific conversions from SH to dry tissue mass were not available, conversions from the nearest available estuary within the same ecoregion (Spalding et al. 2007) were applied. All estuaries represented have predominantly subtidal oyster populations (see Table 2 for a complete list of estuaries).

We collated monthly mean water temperature data for all 13 estuaries from NOAA, USGS, and the National Estuarine 
Table 2 Filtration by historic and present oyster populations, and for 1 ha of oyster ground at either historic or present oyster densities

\begin{tabular}{|c|c|c|c|c|c|c|c|}
\hline Estuary & State & $\begin{array}{l}\text { Historic } \\
\text { volume filtered } \\
\left(1,000 \mathrm{~m}^{3} \mathrm{~h}^{-1}\right)\end{array}$ & $\begin{array}{l}\text { Present volume } \\
\text { filtered } \\
\left(1,000 \mathrm{~m}^{3} \mathrm{~h}^{-1}\right)\end{array}$ & $\begin{array}{l}\text { Historic area } \\
\text { (ha) and density } \\
\left(\text { (indm }^{-2} \text { ) }\right.\end{array}$ & $\begin{array}{l}\text { Present area } \\
\text { (ha) and density } \\
\left(\text { (indm }^{-2} \text { ) }\right.\end{array}$ & $\begin{array}{l}\text { Volume filtered } \\
\text { by } 1 \text { ha at } \\
\text { historic density } \\
\left(1,000 \mathrm{~m}^{3} \mathrm{~h}^{-1}\right)\end{array}$ & $\begin{array}{l}\text { Volume filtered } \\
\text { by } 1 \text { ha at } \\
\text { present density } \\
\left(1,000 \mathrm{~m}^{3} \mathrm{~h}^{-1}\right)\end{array}$ \\
\hline Hudson River/Raritan Bay & $\mathrm{NY} / \mathrm{NJ}$ & $1,604(0.07)$ & $272(0.01)$ & $1,660(17.5)$ & $402(15.5)$ & 0.97 & 0.68 \\
\hline Delaware Bay & $\mathrm{NJ} / \mathrm{DE}$ & $23,718(0.36)$ & $7,567(0.11)$ & $25,149(17.5)$ & $11,471(15.5)$ & 0.94 & 0.66 \\
\hline Tangier and Pocomoke Sound & $\mathrm{MD} / \mathrm{VA}$ & $3,718(0.31)$ & $3,014(0.25)$ & $35,536(1.5)$ & $7,126(11.9)$ & 0.10 & 0.42 \\
\hline York River & $\mathrm{VA}$ & $727(0.24)$ & $109(0.04)$ & $698(19.2)$ & $161(14.8)$ & 1.04 & 0.68 \\
\hline James River & VA & $4,993(0.47)$ & $766(0.07)$ & $4,467(14.5)$ & $2,410(8.4)$ & 1.12 & 0.32 \\
\hline Apalachicola Bay & FL & $2,646(0.24)$ & $22,573(2.02)$ & $2,695(29.2)$ & $3,491(157.6)$ & 0.98 & 6.47 \\
\hline Mobile Bay & $\mathrm{AL}$ & $2,911(0.31)$ & $622(0.07)$ & $1,151(31.4)$ & $1,045(11.2)$ & 2.53 & 0.60 \\
\hline West Mississippi Sound & AL/MS & $7,533(1.08)$ & $566(0.08)$ & $3,391(57.5)$ & $6,490(1.7)$ & 2.22 & 0.09 \\
\hline Galveston Bay & $\mathrm{TX}$ & $73,997(11.88)$ & $2,313(0.37)$ & $12,950(57.5)$ & $10,795(4.1)$ & 5.71 & 0.21 \\
\hline Matagorda Bay & $\mathrm{TX}$ & 87,007 (50.47) & $499(0.29)$ & $16,679(57.5)$ & $2,229(5.2)$ & 5.22 & 0.22 \\
\hline San Antonio Bay & $\mathrm{TX}$ & $13,875(7.96)$ & $444(0.25)$ & $2,590(57.5)$ & $2,158(4.2)$ & 5.36 & 0.21 \\
\hline Aransas Bay & $\mathrm{TX}$ & $20,768(17.47)$ & $381(0.32)$ & 3,885 (57.5) & $482(12.4)$ & 5.35 & 0.79 \\
\hline Corpus Christi Bay & $\mathrm{TX}$ & $19,327(13.89)$ & $20(0.01)$ & $3,367(57.5)$ & $290(1.4)$ & 5.74 & 0.07 \\
\hline
\end{tabular}

The proportion of the estuary filtered within the residence time is given in parentheses below the volume. All estimates represent mean summer filtration (June, July, August). Also shown are historic and present areas of oyster ground (in hectares) and, in parentheses, mean oyster density (ind per square meter)

Research Reserve network. We then applied our fieldbased filtration model to the present and historic extent, and the mean density of both size classes of oyster in each estuary, to determine the change in this ecosystem service over time. As we know of no published data illustrating differences in filtration rate between intertidal and subtidal oysters of the same size, we made no alteration to the model in order to represent subtidal reefs. We assumed no change in mean monthly water temperature or $\mathrm{SH}$-biomass relationship between time periods. For each estuary, we estimated the filtration capacity of the population historically and presently, across all seasons. We summarized and examined the change in the total volume filtered and the volume filtered per unit area over time. We used the Sharipo-Wilk test to determine whether data were non-normally distributed. All statistics were run in $\mathrm{R}$ version 2.13.1 (2011-07-08).

We then estimated the potential ecological impact of the change, by relating the volume filtered to the estuary volume and residence time listed in Bricker et al. (2007). Residence time is defined as the mean transit time of freshwater through the estuary. We use the term full estuary filtration to describe the situation where the oyster population filters more than the entire volume of the estuary within the residence time of water in that estuary. We recognize that this does not equate to complete filtration of all estuarine waters and does not account for phytoplankton production, but believe that this number nonetheless provides a useful indicator of the volume of filtration relative to water flow (Smaal and Prins 1993; Dame 2011).

\section{Results}

We estimate that reefs with oyster densities typical of modern oyster populations would filter a median of $0.15 \times 10^{3} \mathrm{~m}^{3}$ $\mathrm{ha}^{-1} \mathrm{~h}^{-1}$ (range, $0.06 \times 10^{3}$ to $6.47 \times 10^{3} \mathrm{~m}^{3} \mathrm{ha}^{-1} \mathrm{~h}^{-1}$ ) in summer months, as compared to $0.92 \times 10^{3} \mathrm{~m}^{3} \mathrm{ha}^{-1} \mathrm{~h}^{-1}$ historically (range, $0.1 \times 10^{3}$ to $5.74 \times 10^{3} \mathrm{~m}^{3} \mathrm{ha}^{-1} \mathrm{~h}^{-1}$ ). An overview of estuary-specific mean filtration rates is provided in Table 2 .

The volume of water filtered by oyster populations in the USA has declined since c. 1900 in 12 of the 13 estuaries examined, with nine of the estuaries undergoing declines in mean summer filtration greater than $80 \%$ and an $85 \%$ median decline over all (Table 3). Both the Atlantic coast and the Gulf of Mexico coast were impacted (83 and $97 \%$ median loss, respectively), although these could be characterized differently, with no significant difference in filtration per unit area on the Atlantic coast from Wilcoxon test ( $W=$ $20, p>0.05)$ and a dramatic decline in mean filtration per unit area from $4.9 \times 10^{3}$, s.e. 0.67 , to $1.0 \times 10^{3}$, s.e. $0.77 \mathrm{~m}^{3}$ $\mathrm{h}^{-1} \mathrm{ha}^{-1}$ on the Gulf of Mexico coast (Wilcoxon test, $W=56$, $p=0.01$, Table 2). The notable exception to this trend was Apalachicola Bay, FL, which has an oyster population estimated at greater than historic, both with regard to areal extent and density (zu Ermgassen et al. 2012).

Historically, six of the estuaries contained oyster populations capable of full estuary filtration during summer months; this number has subsequently declined to one (Table 3 ). The proportion of the estuary volume filtered within its residence time varied widely across seasons and between estuaries 
Table 3 Proportion of the volume of each estuary that may be filtered by the historic and current populations of oysters, across seasons

\begin{tabular}{|c|c|c|c|c|c|c|c|c|c|c|c|c|}
\hline \multirow[b]{2}{*}{ Estuary } & \multirow[b]{2}{*}{ State } & \multirow[b]{2}{*}{ Volume $\left(1,000 \mathrm{~m}^{3}\right)$} & \multirow[b]{2}{*}{$\begin{array}{l}\text { Residence } \\
\text { time (days) }\end{array}$} & \multicolumn{4}{|c|}{$\begin{array}{l}\text { Historic proportion of bay filtered } \\
\text { with the residence time }\end{array}$} & \multicolumn{4}{|c|}{$\begin{array}{l}\text { Present proportion of bay filtered } \\
\text { with the residence time }\end{array}$} & \multirow[b]{2}{*}{ Mean $\%$ change } \\
\hline & & & & Spring & Summer & Fall & Winter & Spring & Summer & Fall & Winter & \\
\hline Hudson River/Raritan Bay & NY/NJ & $4,897,870$ & 9 & 0.00 & 0.07 & 0.03 & 0.00 & 0.00 & 0.01 & 0.01 & 0.00 & -83 \\
\hline Delaware Bay & $\mathrm{NJ} / \mathrm{DE}$ & $12,668,400$ & 8 & 0.02 & 0.36 & 0.19 & 0.00 & 0.01 & 0.07 & 0.06 & 0.00 & -68 \\
\hline Tangier and Pocomoke Sounds & $\mathrm{MD} / \mathrm{VA}$ & $3,477,530$ & 12 & 0.07 & 0.31 & 0.17 & 0.00 & 0.05 & 0.21 & 0.14 & 0.00 & -19 \\
\hline York River & $\mathrm{VA}$ & 786,920 & 11 & 0.04 & 0.24 & 0.13 & 0.00 & 0.01 & 0.03 & 0.02 & 0.00 & -85 \\
\hline James River & VA & $2,060,800$ & 8 & 0.08 & 0.47 & 0.24 & 0.00 & 0.01 & 0.06 & 0.04 & 0.00 & -85 \\
\hline Apalachicola Bay & $\mathrm{FL}$ & $1,073,330$ & 4 & 0.17 & 0.24 & 0.20 & 0.02 & 1.48 & 2.10 & 1.69 & 0.19 & 753 \\
\hline Mobile Bay & $\mathrm{AL}$ & $2,060,890$ & 9 & 0.21 & 0.31 & 0.24 & 0.02 & 0.04 & 0.07 & 0.05 & 0.00 & -79 \\
\hline West Mississippi Sound & $\mathrm{AL} / \mathrm{LA}$ & $3,841,830$ & 23 & 0.73 & 1.08 & 0.87 & 0.06 & 0.06 & 0.08 & 0.07 & 0.00 & -92 \\
\hline Galveston Bay & $\mathrm{TX}$ & $2,242,240$ & 15 & 8.86 & 11.88 & 10.23 & 0.94 & 0.28 & 0.39 & 0.32 & 0.03 & -97 \\
\hline Matagorda Bay & $\mathrm{TX}$ & $1,572,150$ & 38 & 45.13 & 50.47 & 51.18 & 6.49 & 0.26 & 0.32 & 0.29 & 0.04 & -99 \\
\hline San Antonio Bay & $\mathrm{TX}$ & 346,330 & 8 & 6.70 & 7.69 & 7.50 & 0.97 & 0.21 & 0.27 & 0.24 & 0.03 & -97 \\
\hline Aransas Bay & $\mathrm{TX}$ & 513,520 & 18 & 15.97 & 17.47 & 16.74 & 2.49 & 0.29 & 0.35 & 0.31 & 0.05 & -98 \\
\hline Corpus Christi Bay & $\mathrm{TX}$ & $1,535,990$ & 46 & 11.12 & 13.89 & 13.94 & 2.42 & 0.01 & 0.01 & 0.01 & 0.00 & -100 \\
\hline
\end{tabular}

Seasons defined as: spring (March, April, May); summer (June, July, August), fall (September, October, November), and winter (December, January, February)

(Table 3). Estuaries in the western Gulf of Mexico were typically filtered multiple times within their residence times historically during the summer (six of eight), while estuaries in the northeast were not (zero of five) (Fig. 2).

\section{Discussion}

Coastal systems have undergone unprecedented change over the past century (Jackson et al. 2001). While the role that oysters play in improving water quality is increasingly

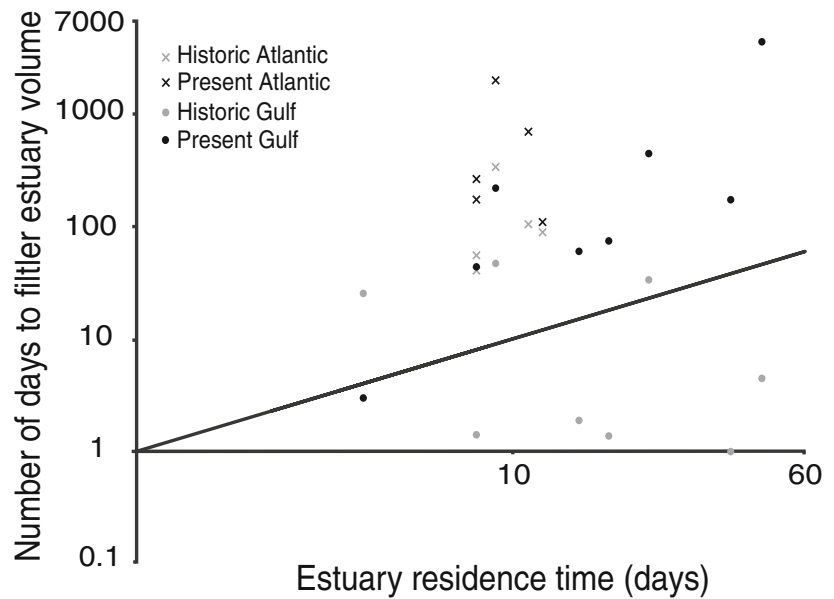

Fig. 2 Illustration of current and historic number of days until the oyster population filtered a volume equivalent to the volume of the estuary against the residence time of the estuary. The black line represents the point at which the filtration time equals the residence time. Points above the line are not filtering the full volume of the estuary within the residence time valuable given the high incidence of eutrophication (Bricker et al. 2007), the provision of this ecosystem service has declined precipitously over the past century (Table 3, Fig. 2).

We report a near universal decline of the filtering capacity of oyster habitats by more than $80 \%$. Our results suggest that 100 years ago, filtration by oysters was likely to have been a major ecological function, achieving full estuary filtration in many estuaries (Table 3, Fig. 2). This reduction in filtration capacity is likely to have caused substantial changes to the ecosystem function of estuaries (Newell 1988; Dame et al. 2002). While the ecological importance of a healthy oyster population has been the focus of much attention in the Chesapeake (e.g., Ulanowicz and Tuttle 1992; Fulford et al. 2007), the decline in the ecosystem services provided by healthy oyster habitats in US estuaries more generally remains poorly appreciated and understudied. Although increases in oyster filtration alone are unlikely to resolve the water quality concerns of many US estuaries (Cerco and Noel 2007), it may be possible to restore this ecosystem service to levels at which it will have some beneficial ecological impact locally (Newell and Koch 2004).

The decline in filtration capacity in estuaries spanning such a large area is striking. While the decline in filtration capacity appears to have been greater in the Gulf of Mexico than in the North Atlantic (Table 3, Fig. 2), this is certainly at least in part because the surveys conducted along the North Atlantic coast were undertaken after exploitation rates had peaked and thus reflected an already shifted baseline with low oyster densities (zu Ermgassen et al. 2012, Table 2). For example, our 1887 historic baseline for Tangier and 
Pocomoke Sound (Chesapeake Bay, Atlantic coast) documented oyster densities 2-7-fold lower than observations from 30 years earlier (Winslow 1887), while even this earlier 1850 s estimate is likely to have been dramatically lower than precolonial densities (Newell 1988; Kirby 2004). By contrast, the historic surveys undertaken in the Gulf of Mexico were conducted with the caveat that many oyster reefs remained undiscovered (Moore 1907). As such, our estimates of the historic level of services in the northeast likely represent a significantly shifted baseline.

All historic baselines should be considered relative to their date of origin, as they may be shifted from pristine conditions (Roberts 2007). This non-pristine baseline is further supported by observations that mean SH in precolonial shell deposits in South Carolina were found to be $62 \%$ greater than mean harvested SH in 1938 (Lunz 1938). Such age and size truncation is typical of harvested species (Hutchings and Reynolds 2004) and would have a marked impact on population-level filtration rates (Mann et al. $2009 a, b)$. If a moderate correction of assuming fourtimes-higher densities $\left(6.5\right.$ oysters $\left./ \mathrm{m}^{2}\right)$ and precolonial size distributions is applied to the historic extent in Tangier and Pocomoke Sound, this would result in approximately a 7fold increase in filtration capacity and the estuary being filtered multiple times within its residence time. As such, it is reasonable to expect that oysters in many of the northeastern US estuaries would have exerted full estuary filtration capacity prior to the industrial exploitation of oysters.

We concur with a number of authors who have previously asserted that oysters would historically have been dominant filter feeders with significant ecological impacts through filtration in many estuaries (Newell 1988; Cerco and Noel 2007; Mann et al. 2009a, b). Our historical data represent a shifted baseline, particularly in the northeastern USA, but such quantitative historical data help to avoid further shifts in baselines and ensure that modern management goals are not misguided (Swetnam et al. 1999). Modern management goals should utilize such historical data, but in a broader context. For example, ecologically relevant restoration goals might best focus on delivery of the desired ecosystem services (Jackson and Hobbs 2009), aided by our understanding of their relative importance in the face of a changing environmental landscape (Swetnam et al. 1999). Our model and bay-specific data provide the basis for such comprehensive goal setting.

In contrast to the situation on the Atlantic Coast, it is noteworthy that for Apalachicola Bay in the Gulf of Mexico, we estimate present day levels of filtration that are greater than historic estimates. Apalachicola Bay has undergone intensive management of the oyster resource including extensive shell planting since the historic survey efforts which has led to increased areal extent of oysters, in addition to the recorded densities being higher (zu Ermgassen et al. 2012). It is noteworthy that this is one of the few estuaries in which harvesting is primarily by tonging, and dredging is not allowed. It is widely agreed that tonging is a less-destructive harvest method than dredging (Lenihan and Peterson 2004), and further work may well reveal that this has been a critical factor in ensuring the long-term sustainable benefits that appear to be delivered in these estuaries.

Our model of filtration rates is the first to incorporate field measurements from in situ oyster populations, and therefore to represent whole-reef filtration. When converted to the same unit, the filtration rate estimated by our model is lower than the maximum filtration rate of $11.5 \mathrm{lh}^{-1}$ used by Cerco and Noel (2007) in their model for the Chesapeake. This is as would be expected if the use of field data were, as we have assumed, a useful surrogate where the environmental data required to modify maximum filtration rate are absent.

Considering filtration relative to residence time can be a useful indicator of the potential for oysters to have an ecologically significant impact on an estuary (Dame 2011). However, even when undisturbed, estuaries exhibit high variability in sediment load, planktonic productivity, depth, residence time, and natural abundance of oysters (Bricker et al. 2007; zu Ermgassen et al. 2012), all of which influence the extent to which oyster filtration may impact water quality (Officer et al. 1982; Pomeroy et al. 2006; Cerco and Noel 2007). Temporal mismatching between phytoplankton production and peak oyster filtration may also limit the potential for oyster populations to have a regulating influence. Additionally, the impact of filtration on seston drawdown on large scales cannot be directly inferred from filtration rates due to the influences of wave action (Porter et al. 2004), the unequal distribution of oysters (Cerco and Noel 2007), and imperfect mixing within the estuary (Pomeroy et al. 2006). This in turn may lead to variable impacts of oyster filtration on nutrient cycling within the bay, as the biodeposition of seston may stimulate enhanced denitrification and anammox in the sediments (Dame 2011). In this context, the point at which the population filtration rate matches the residence time simply represents a point on a continuum, albeit one that may provide a useful guide for estimating the ecological impact.

While our estimates of change over time stress the extreme nature of the losses of filtration by oysters, our results also highlight that changes in management of oyster reefs, particularly in their diminished condition, can have a significant influence on the amount of filtration provided in the future. In particular, management decisions that lead to higher average densities on existing reef footprint, or expansions of reef area through restoration coupled with increasing oyster size or density, could move a number of estuaries toward a state where oysters can once more play a role in supporting water quality (Table 3 ). 
Currently, oyster restoration efforts and goals are accounted for by their areal extent (e.g., NOAA 2012); however, the volume of water filtered by oysters is not solely a function of the area of oyster habitat, but also of the density and size frequency of the oysters. Therefore, as restoration of oyster habitat for ecosystem services gains momentum, it will be critical to devise appropriate metrics to assess the contribution of restoration projects toward those target ecosystem services. Any restoration undertaken with the goal of water filtration needs to account for the density and size distribution of oysters in addition to the area restored. Without these data, the contribution of restoration projects and their progress toward their ecosystem service goals will remain unknown.

This study provides a unique numerical insight into the dramatic functional changes that can accompany the degradation of an estuarine habitat. Even from "non-pristine" historical baselines, it is clear that a significant and nearly universal loss of ecosystem services has occurred in US estuaries, which has gone hand in hand with the loss and degradation of oyster reef habitat.

Acknowledgments This work was supported by a grant from the National Fish and Wildlife Foundation (award no. 2009-0078-000) and by the National Partnership between The Nature Conservancy and the National Oceanic and Atmospheric Administration Communitybased Restoration Program (award nos. NA07NMF4630136 and NA10NMF463008). Additional funding support for the project was provided by The Nature Conservancy-Shell Partnership and The Turner Foundation, Inc. The authors would like to thank D. Bushek, S. Geiger, and M. LaPeyre for preparing and sharing shell height-biomass relationships and J.R. Gair for assistance with model development.

Open Access This article is distributed under the terms of the Creative Commons Attribution License which permits any use, distribution, and reproduction in any medium, provided the original author(s) and the source are credited.

\section{References}

Beck, M.W., R.D. Brumbaugh, L. Airoldi, A. Carranza, L.D. Coen, C. Crawford, O. Defeo, G.J. Edgar, B. Hancock, M. Kay, H.S. Lenihan, M.W. Luckenbach, C.L. Toropova, G. Zhang, and X. Guo. 2011. Oyster reefs at risk and recommendations for conservation, restoration and management. BioScience 61: 107-116.

Berg, J.A., and R.I.E. Newell. 1986. Temporal and spatial variations in the composition of seston available to the suspension feeder Crassostrea virginica. Estuarine, Coastal and Shelf Science 23: 375-386.

Beseres Pollack, J., H.-C. Kim, E.K. Morgan, and P.A. Montagna. 2011. Role of flood disturbance in natural oyster (Crassostrea virginica) population maintenance in an estuary in South Texas, USA. Estuaries and Coasts 34: 187-197.

Bricker, S., B. Longstaff, W. Dennison, A. Jones, K. Boicourt, C. Wicks, and J. Woerner. 2007. Effects of nutrient enrichment in the nation's estuaries: a decade of change. Silver Spring: National Centers for Coastal Ocean Science.
Bromberg, K.D., and M.D. Bertness. 2005. Reconstructing New England salt marsh losses using historical maps. Estuaries 28: 823-832.

Cerco, C.F., and M.R. Noel. 2005. Assessing a ten-fold increase in the Chesapeake Bay native oyster population. A report to the EPA Chesapeake Bay Program. Vicksburg: US Army Engineer Research and Development Center.

Cerco, C.F., and M.R. Noel. 2007. Can oyster restoration reverse cultural eutrophication in Chesapeake Bay? Estuaries and Coasts 30: $331-343$.

Churchill Jr., E.P. 1920. The oyster and the oyster industry of the Atlantic and Gulf coasts. Appendix VIII to the report of the U. S. Commissioner of Fisheries for 1919. Washington D.C.: Department of Commerce, Government Printing Office.

Cranford, P.J., D.A. Evans, and S.E. Shumway. 2011. Bivalve filter feeding: varibility and limits of the aquaculture biofilter. In Shellfish aquaculture and the environment, ed. S.E. Shumway, 81-124. Oxford: Wiley.

Dame, R., D. Bushek, D. Allen, A. Lewitus, D. Edwards, E. Koepfler, and L. Gregory. 2002. Ecosystem response to bivalve density reduction: management implications. Aquatic Ecology 36: 51-65.

Dame, R.F. 2011. Ecology of marine bivalves: an ecosystem approach. Boca Raton: CRC Press.

Dame, R.F., J.D. Spurrier, and R.G. Zingmark. 1992. In situ metabolism of an oyster reef. Journal of Experimental Marine Biology and Ecology 164: 147-159.

Dame, R.F., R.G. Zingmark, and E. Haskin. 1984. Oyster reefs as processors of estuarine materials. Journal of Experimental Marine Biology and Ecology 83: 239-247.

Diaz, S., J. Fargione, F.S. Chapin III, and D. Tilman. 2006. Biodiversity loss threatens human well-being. PLoS Biology 4: e277.

Doering, P.H., and C.A. Oviatt. 1986. Application of filtration rate models to field populations of bivalves: an assessment using experimental mesocosms. Marine Ecology Progress Series 31: $265-275$.

Epifanio, C.E., and J. Ewart. 1977. Maximum ration of four algal diets for the oyster Crassostrea virginica Gmelin. Aquaculture 11: 13-29.

Fearnside, P.M. 2005. Deforestation in Brazilian Amazonia: history, rates, and consequences. Conservation Biology 19: 680-688.

Fulford, R.S., D.L. Breitburg, R.I.E. Newell, W.M. Kemp, and M. Luckenbach. 2007. Effects of oyster population restoration strategies on phytoplankton biomass in Chesapeake Bay: a flexible modeling approach. Marine Ecology Progress Series 336: 43-61.

Gibbs, H.K., S. Brown, J.O. Niles, and J.A. Foley. 2007. Monitoring and estimating tropical forest carbon stocks: making REDD a reality. Environmental Research Letters 2: 045023. doi:10.1088/ 1748-9326/2/4/045023.

Grizzle, R.E., J.K. Greene, and L.D. Coen. 2008. Seston removal by natural and constructed intertidal eastern oyster (Crassostrea virginica) reefs: a comparison with previous laboratory studies, and the value of in situ methods. Estuaries and Coasts 31: 12081220.

Grizzle, R.E., J.K. Greene, M.W. Luckenbach, and L.D. Coen. 2006. A new in situ method for measuring seston uptake by suspensionfeeding bivalve molluscs. Journal of Shellfish Research 25: 643649.

Harding, J.M., R. Mann, M.J. Southworth, and J.A. Wesson. 2010. Management of the Piankatank River, Virginia, in support of oyster (Crassostrea virginica, Gmelin, 1791) fishery repletion. Journal of Shellfish Research 29: 867-888.

Harsh, D.A. and M.W. Luckenbach. 1999. Materials processing by oysters in patches: interactive roles of current speed and seston composition. In: M.W. Luckenbach, R. Mann and J.A. Wesson (eds) Oyster reef habiatat restoration: a synopsis and synthesis of approaches. Virginia Institute of Marine Science, School of Marine Science, College of William and Mary, VIMS Press, pp. 251-265. 
Hutchings, J.A., and J.D. Reynolds. 2004. Marine fish population collapses: consequences for recovey and extinction risk. BioScience 54: 297-309.

Jackson, J.B.C., M.X. Kirby, W.H. Berger, K.A. Bjorndal, L.W. Botsford, B.J. Bourque, R.H. Bradbury, R. Cooke, J. Erlandson, J.A. Estes, T.P. Hughes, S. Kidwell, C.B. Lange, H.S. Lenihan, J.M. Pandolfi, C.H. Peterson, R.S. Steneck, M.J. Tegner, and R.R. Warner. 2001. Historical overfishing and the recent collapse of coastal ecosystems. Science 293: 629-637.

Jackson, S.T., and R.J. Hobbs. 2009. Ecological restoration in the light of ecological history. Science 325: 567-569.

Kirby, M. 2004. Fishing down the coast: historical expansion and collapse of oyster fisheries along continental margins. Proceedings of the National Academy of Sciences 101: 13096-13099.

Lambin, E.F. 1999. Monitoring forest degradation in tropical regions by remote sensing: some methodological issues. Global Ecology and Biogeography 8: 191-198.

Lenihan, H.S., and C.H. Peterson. 2004. Conserving oyster reef habitat by switching from dredging and tonging to diver hand-harvesting. Fishery Bulletin 102: 298-305.

Liddel, M. K. 2008. A von Bertalanffy based model for the estimation of oyster (Crassostrea virginica) growth on restored oyster reefs in Chesapeake Bay. $\mathrm{PhD}$ thesis, Marine, Estuarine and Environmental Sciences, University of Maryland. p. 159.

Loosanoff, V.L. 1958. Some aspects of behavior of oysters at different temperatures. The Biological Bulletin 114: 57-70.

Lunz, G.R. 1938. Comparison between pre-colonial and present-day oysters. Science 87: 367.

Mackenzie, C.L. 2007. Causes underlying the historical decline in eastern oyster (Crassostrea virginica Gmelin, 1791) landings. Journal of Shellfish Research 26: 927-938.

Mann, R., J.M. Harding, and M.J. Southworth. 2009a. Reconstructing pre-colonial oyster demographics in the Chesapeake Bay, USA. Estuarine, Coastal and Shelf Science 85: 217-222.

Mann, R., M.J. Southworth, J.M. Harding, and J.A. Wesson. 2009b. Population studies of the native oyster, Crassostrea virginica, (Gmelin, 1791) in the James River, Virginia, USA. Journal of Shellfish Research 28: 193-220.

Millennium Ecosystem Assessment. 2005. Ecosystems and human wellbeing: current state and trends. Washington D.C.: Island Press.

Moore, H.F. 1907. Survey of oyster bottoms in Matagorda Bay. Washington D.C.: GPO.

Moore, H.F. 1910. Condition and extent of the oyster beds of James River, Virginia. Washington, D.C.: GPO.

Newell, R.I.E. 1988. Ecological changes in Chesapeake Bay: are they the result of overharvesting the American oyster, Crassostrea virginica? Understanding the estuary: advances in Chesapeake Bay Research. Baltimore: Chesapeake Research Consortium Publication.

Newell, R.I.E., and E.W. Koch. 2004. Modeling seagrass density and distribution in response to changes in turbidity stemming from bivalve filtration and seagrass sediment stabilization. Estuaries 27: 793-806.

Newell, R.I.E., and C.J. Langdon. 1996. Mechanisms and physiology of larval and adult feeding. In The eastern oyster Crassostrea virginica, ed. V.S. Kennedy, R.I.E. Newell, and A.F. Eble, 185229. A Maryland Sea Grant Book: College Park.

NOAA. 2012. National Oceanic and Atmospheric Administration restoration atlas. .http://seahorse2.nmfs.noaa.gov/restoration_atlas/ src/html/index.html. Accessed Feb 3, 2012.

Officer, C.B., T.J. Smayda, and R. Mann. 1982. Benthic filter feeding: a natural eutrophication control. Marine Ecology Progress Series 9: 203-210.

Pomeroy, L.R., C.F. D'Elia, and L.C. Schaffner. 2006. Limits to topdown control of phytoplankton by oysters in Chesapeake Bay. Marine Ecology Progress Series 325: 301-309.
Porter, E.T., J.C. Cornwell, L.P. Sanford, and R.I.E. Newell. 2004. Effect of oysters Crassostrea virginica and bottom shear velocity on benthic-pelagic coupling and estuarine water quality. Marine Ecology Progress Series 271: 61-75.

Powell, E.N., K.A. Ashton-Alcox, J.N. Kraeuter, S.E. Ford, and D. Bushek. 2008. Long-term trends in oyster population dynamics in Delaware Bay: regime shifts and reponse to disease. Journal of Shellfish Research 27: 729-755.

Powell, E.N., E.E. Hofmann, J.M. Klinck, and S.M. Ray. 1992. Modeling oyster populations I. A commentary on filtration rate. Is faster always better? Journal of Shellfish Research 11: 387-398.

Press, W.H., S.A. Teukolsky, W.T. Vetterling, and B.P. Flannery. 2007. Numerical recipes: the art of scientific computing. New York: Cambridge University Press.

Riisgaard, H.U. 1988. Efficiency of particle retention and filtration rate in 6 species of Northeast American bivalves. Marine Ecology Progress Series 45: 217-223.

Roberts, C.M. 2002. Deep impact: the rising toll of fishing in the deep sea. Trends in Ecology \& Evolution 17: 242-245.

Roberts, C.M. 2007. The unnatural history of the sea. The past and future of humanity and fishing. London: Gaia.

Shumway, S.E., T.L. Cucci, R.C. Newell, and C.M. Yentsch. 1985. Particle selection, ingestion, and absorption in filter-feeding bivalves. Journal of Experimental Marine Biology and Ecology 91: 77-92.

Smaal, A.C., and T.C. Prins. 1993. The uptake of organic matter and the release of inorganic nutrients by bivalve suspension feeder beds. In Bivalve filter feeders in estuarine and coastal ecosystem processes, ed. R.F. Dame, 273-298. Heidelberg: Springer.

Sommer, A. 1976. Attempt at an assessment of the world's tropical moist forests. Unasylva 28: 5-24.

Spalding, M.D., H.E. Fox, G.R. Allen, N. Davidson, Z.A. Ferdana, M.A.X. Finlayson, B.S. Halpern, M.A. Jorge, A.L. Lombana, S.A. Lourie, K.D. Martin, E. McManus, J. Molnar, C.A. Recchia, and J. Robertson. 2007. Marine ecoregions of the world: a bioregionalization of coastal and shelf areas. BioScience 57: 573583.

Swetnam, T.W., C.D. Allen, and J.L. Betancourt. 1999. Applied historical ecology: using the past to manage for the future. Ecological Applications 9: 1189-1206.

Turner, S.J., S.F. Thrush, J.E. Hewitt, V.J. Cummings, and G. Funnell. 1999. Fishing impacts and the degradation or loss of habitat structure. Fisheries Management and Ecology 6: 401-420.

Ulanowicz, R.E., and J.H. Tuttle. 1992. The trophic consequences of oyster stock rehabilitation in Chesapeake Bay. Estuaries 15: 298306.

Walne, P.R. 1972. The influence of current speed, body size and water temperature on the filtration rate of five species of bivalves. Journal of the Marine Biological Association of the United Kingdom 52: 345-374.

Wilberg, M.J., M.E. Livings, J.S. Barkman, B.T. Morris, and J.M. Robinson. 2011. Overfishing, disease, habitat loss, and potential extirpation of oysters in upper Chesapeake Bay. Marine Ecology Progress Series 436: 131-144.

Wilson-Ormond, E.A., E.N. Powell, and S.M. Ray. 1997. Short-term and small-scale variation in food availability to natural oyster populations: food, flow and flux. Marine Ecology 18: 1-34.

Winslow, F. 1887. Deterioration of American oyster-beds. The Popular Science Monthly 20: 29-43.

zu Ermgassen, P.S.E., M.D. Spalding, B. Blake, L.D. Coen, B. Dumbauld, S. Geiger, J.H. Grabowski, R. Grizzle, M. Luckenbach, K.A. McGraw, B. Rodney, J.L. Ruesink, S.P. Powers, and R.D. Brumbaugh. 2012. Historical ecology with real numbers: past and present extent and biomass of an imperilled estuarine ecosystem. Proceedings of the Royal Society B 279: 3393-3400. 